\title{
Performance figures of invasive cardiology in Germany 2006 and 2007 focussing on coronary artery disease
}

\author{
Dieter Horstkotte - Marcus Wiemer • \\ Frank van Buuren
}

Received: 24 June 2010/Accepted: 1 October 2010/Published online: 21 October 2010

(C) Springer-Verlag 2010

Performance figures of the catheter laboratories (CL) operated in Germany have been published recently for the years 2006 [6] and 2007 [7]. The 25th anniversary report will follow shortly. Since 1985, these annual reports are, the only valid sources of information reporting character and frequency of diagnostic and therapeutic cardiac procedures performed in Europe's largest medical community $[9,12]$. Governmental registries that came up only in the last 10 years ("BQS" for inpatient procedures and "Quik" for outpatient procedures), provided incomplete data sets in their first years as no complete documentations were acquired and the number of requested items was considerably low [1, 18, 32].

Participation in this registry is voluntary, but with a nonresponder rate as low as $1.5 \%$ in 2007 well accepted. Data collection and processing is strictly anonymous resulting in some shortcomings: (a) although anonymously, reported data may be incorrect which cannot be re-checked; (b) the registry does not provide quality insurance data; and (c) to generate a more or less complete data set, some institutions are contacted up to ten times to finally have their data available. This results in a significant publication delay.

To prevent non-uniform countings, every centre is annually provided with an explanation on how data should be reported, e.g. procedures with diagnostic angiogram and subsequent PCI in one session have to be counted as one angiogram and one PCI.

In 2007, 742 CL (2006: $653 \mathrm{CL}$; +13.6\%) were operated by 547 (2006: $513 ;+6.6 \%)$ institutions. Hence most

D. Horstkotte $\cdot$ M. Wiemer $\cdot$ F. van Buuren $(\varangle)$

Department of Cardiology, Heart and Diabetes Centre North

Rhine-Westphalia, Ruhr University Bochum, Georgstr. 11,

32545 Bad Oeynhausen, Germany

e-mail: fvbuuren@hdz-nrw.de institutions in Germany are low-volume centres operating only one CL (1.27 CL per institution in 2006 and 1.36 in 2007).

In the last 5 years (2002-2007), the number of diagnostic and therapeutic coronary procedures in Germany increased steadily from 641,973 to $830,658(+29.4 \%)$ and 208,178 to $298,724(+43.5 \%)$, respectively, keeping Germany in the leading European position regarding both, the frequency of diagnostic (1,010/100,000 population) and therapeutic coronary procedures $(363 / 100,000)$ per population [7]. In 2007, the average volume per CL has been as low as 1,119 coronary angiographies and 403 coronary interventions. Compared to the 2006 numbers, this is a decrease per CL of 9.2 and $9.4 \%$, respectively.

These figures are remarkable for several reasons:

1. Despite the fact that morbidity and mortality of ischaemic heart disease does not differ much among medical countries in Central Europe, the rates of both diagnostic and therapeutic coronary procedures vary widely [9, 19]. As recent randomized trials seem to indicate that coronary interventions in patients with chronic stable angina do not result in an improvement of outcomes [3, 4, 29], it is not unexpected that the high rates of coronary procedures performed in Germany do not translate into corresponding reduction in coronary events.

2. Although steadily increasing since 1984 (1984: 4.9, 1994: 24.7, 2004: 35.0, 2006: 36.1), the intervention ratio (number of catheter-based coronary interventions per 100 diagnostic procedures) is low and in 2007 for the first time since 1999 it was lower than that in the previous year. Following the same European guidelines on the indication for catheter-based coronary procedures [31], the intervention ratios in 2001 and 
2005, respectively, 48 and $42 \%$ for Norway, 39 and $46 \%$ for Switzerland and 39 and 54\% for France, have been much higher in 2005 [9, 10, 23]. In Germany the intervention ratio was lower: $32 \%$ in 2001 and $35 \%$ in 2005. New comparing data for the year 2008 for the European countries are expected to be published this year. Among other reasons, this may indicate that perhaps driven by the Germany reimbursement system, the indication for coronary angiography is less strict and pretesting [24] and not as stringent as that in our neighbouring countries.

Even considering patients who undergo coronary revascularization surgery and patients in whom a coronary artery disease has to be excluded during routine work-up before non-coronary cardiac surgery, figures remain low: in 2007, 290,726 percutaneous coronary interventions (PCI) were performed in 830,658 patients who had coronary angiography $(36.0 \%)$. In the same year, coronary revascularization surgery (CCI) was performed in 63,364 patients and non-coronary artery cardiac surgery was performed in 29,676 adults [14]. Thus, more than every second coronary angiography did not result in a revascularization procedure or had been done in a population not undergoing cardiothoracic surgery.

Furthermore optimized precatheter diagnostic procedures, especially for myocardial ischaemia, could lead to a relatively higher proportion of caths resulting in interventions [17].

Such preselection with interventions in cases with confirmed ischaemia only might be considered as an indicator of the quality of care. However, the ratio between purely diagnostic and interventional procedures is not considered as a strong indicator of quality.

3. In 2007, 51 institutions in Germany offered diagnostic coronary angiography but not PCI. Taking the average number of diagnostic coronary procedures per CL and the average intervention rate into account, in 2007 more than 22,000 patients were transferred to another institution for PCI (resulting in double procedures) in addition to those at least 5\% PCI referrals who were transferred from low to high-volume centres for expected "complex coronary interventions". The latter figures are included in those number of patients who had no "ad hoc" interventions after angiographic demonstration of coronary artery disease (CAD). Deferring an intervention gives time to discuss the options with the patient, permits interdisciplinary consultation (CCI vs. PCI) and in unclear cases regarding myocardial ischaemia performing stress imaging. Nonetheless, the percentage of patients who did not undergo "ad hoc" but later interventions with $36.8 \%$ (2005), 33.6\% (2006) remained high even in
2007 (30.0\%). On-site FFR might be helpful in patients in whom it is not clear whether a coronary lesion is significant and/or responsible for the patient's symptoms (number of procedures in 2007: 1,109 in 28 institutions). This will result in additional (partially reimbursed costs) but avoid delays and repeated interventions including repeated arterial accesses [30].

4. The average frequency of coronary interventions in Germany per institution and year is low and decreasing (2006: 576, 2007: 546), endangering quality issues. Depending on the number of interventionalists, 81 institutions with less than 200 interventions and 93 institutions with 201-400 interventions in 2008 may not qualify for state-of-the-art PCI [5].

5. Gottwik and Senges [13] recently indicated the close correlation between institutional procedure numbers and the outcome of interventionally treated STEMI patients. These findings have, however, not been confirmed in patients with stable angina.

In Europe there were 951 diagnostic studies and 284 coronary interventions per cathlab (2000) [2]. The US data for 2004 indicated a mean annual PCI volume of $666 \pm 550$ per cathlab [22]. There is a massive discrepancy between the overall number of coronary procedures performed in Germany and the still relatively low percentage of patients with ST elevation myocardial infarction (STEMI) that undergo acute mechanical revascularization. Consequently, mortality rates STEMI remain high in Germany (70.3/100,000 population), while figures for Austria (61.3/100,000 population) and Switzerland (36.0/ 100,000 population) compare favourably. One reason is deregulation allowing every institution to operate a CL despite an already high supply density. One frequent argument is that emergency cases must be managed within short transportation times, although it has been shown that transportation time in nearly all parts of Germany with its dense population is of neglectable importance [28]. The wide spread of CL in Germany not only result in small units with a low overall intervention rate but also in time delays due to ineffective standby services. Although the number of coronary interventions for acute coronary syndromes (ACS) has constantly increased from 61,251 in $2005,62,863$ in $2006(+2.6 \%)$, to 69,738 in 2007 $(+11.0 \%)$, they are still insufficiently low $[16,19,20]$.

In 2002 only $44 \%$ of STEMI patients underwent an acute revascularization procedure. Thirty-seven percent received neither mechanical revascularization nor thrombolysis $[16,20]$. In the Euro Heart Survey ACS-III, the percentage of STEMI patients who underwent reperfusion increased from $77.2 \%$ (2006) to $81.3 \%$ (2008) mainly due to the increase in acute percutaneous coronary interventions [25]. Figures in type 2 diabetics remain even lower 
despite the fact that the prognostic benefit for this patient group is especially high $[16,20]$.

Taking the positive long-term results of PCI with adjuvant drug-eluting stent (DES) implantation as compared to subgroups with no stents or bare metal stent implantations into account $[11,15,21,22,26]$, the current use of DES is considered rather restrictive [27, 28]. Despite the low percentage of PCI patients receiving DES in Germany (24.0\% in 2005 and $29.4 \%$ in 2006) the percentage further decreased in 2007 (27.5\%). In general, this may reflect the economic situation of an average German hospital and the decrease in 2007 in particular may reflect the concerns on the long-term outcome after DES due to acute stent thrombosis arising during the 2007 ESC congress in Barcelona [8].

Nonetheless, the rate of $14 \%$ DES per 100 coronary procedures in Germany in 2005 has been lower at any time than in other European countries, e.g. Austria (66\%), Spain $(61 \%)$ and Portugal (49\%) [9, 10, 23].

The discussion of all these circumstances might lead to the opinion that both, diagnostic and interventional procedures in Germany are done more often than necessary. However, the incidence of coronary artery disease is still rising and increasing number of cathlabs in Germany might dignify this circumstance.

\section{References}

1. Albrecht A, Levenson B, Göhring S, Haerer W, Reifart N, Ringwald G, Troger B, Steering-Committee des QuIK-Registers und die Teilnehmer des QuIk-Registers (2009) Das QuIKRegister des Bundesverbandes Niedergelassener Kardiologen Flächendeckende vergleichende Qualitätssicherung in der Invasivkardiologie. Dtsch Med Wochenschr 134(Suppl 6):S211-S213

2. Balmer F, Rotter M, Togni M, Pfiffner D, Zeiher AM, Maier W, Meier B, Working Group Interventional Cardiology and Coronary Pathophysiology of the European Society of Cardiology (2005) Percutaneous coronary interventions in Europe 2000. Int J Cardiol 101:457-463

3. Boden WE, O'Rourke RA, Teo KK, Hartigan PM, Maron DJ, Kostuk WJ, Knudtson M, Dada M, Harris CL, Chaitman BR, Shaw LJ, Gosseliln G, Nawaz S, Title LM, Gau G, Blaustein AS, Booth DC, Bates ER, Spertus JA, Berman DS, Mancini GBJ, Weintraub WS for the COURAGE Trial Research Group (2007) Optimal medical therapy with or without PCI for stable coronary disease. N Engl J Med 356:1503-1516

4. Boden WE, O'Rourke RA, Teo KK, Maron DJ, Hartigan PM, Sedlis SP, Dada M, Labedi M, Spertus JA, Kostuk WJ, Berman DS, Shaw LJ, Chaitman BR, Mancini GBJ, Weintraub WS on behalf of the COURAGE Trial Investigators (2009) Impact of optimal medical therapy with or without percutaneous coronary intervention on long-term cardiovascular end points in patients with stable coronary artery disease (from the COURAGE Trial). Am J Cardiol 104:1-4

5. Bruckenberger E (2009) Herzbericht 2008. Sektorenübergreifende Versorgungsanalyse zur Kardiologie und Herzchirurgie in
Deutschland sowie vergleichende Daten aus Österreich und der Schweiz. Hannover, Eigenverlag

6. van Buuren F, Horstkotte D (2009) 23. Bericht über die Leistungszahlen der Herzkatheterlabore in der Bundesrepublik Deutschland. Eine Datenerhebung mit Unterstützung der Kommission für Klinische Kardiologie und der Arbeitsgruppen Interventionelle Kardiologie (für die ESC) und Angiologie der Deutschen Gesellschaft für Kardiologie-Herz- und Kreislaufforschung über das Jahr 2006. Kardiologe 3:437-442

7. van Buuren F, Horstkotte D (2009) 24.Bericht über die Leistungszahlen der Herzkatheterlabore in der Bundesrepublik Deutschland. Eine Datenerhebung mit Unterstützung der Kommission für Klinische Kardiologie und der Arbeitsgruppen Interventionelle Kardiologie (für die ESC) und Angiologie der Deutschen Gesellschaft für Kardiologie - Herz- und Kreislaufforschung über das Jahr 2007. Kardiologe 3:512-518

8. Camenzind E, Steg PG, Wijns W (2007) Stent thrombosis late after implantation of first-generation drug-eluting stents: a cause for concern. Circulation 115:1440-1455

9. Cook S, Togni M, Walpoth N, Maier W, Muehlberger V, Legrand V, Milicic D, Zambartas C, Zelizko M, Madsen JK, van Buuren F, Lòpez-Palop R, Peeba M, Koskenkorva J, Vanhanen H, Lablanche JM, Lazaris I, Géza F, Eyjolfsson K, Kearney P, Piscione F, Erglis A, Navickas R, Beissel J, Channam R, Koch K, Deleanu D, Melberg T, Witkowski A, Pereira H, Reho I, Fridrich V, Zorman D, Nilsson T, Oezmen F, Ludman P, Meier B (2006) Percutaneous coronary interventions in Europe 1992-2003. EuroIntervention $1: 374-379$

10. Cook S, Walker A, Hügli O, Togni M, Meier B (2007) Percutaneous coronary interventions in Europe: prevalence, numberical estimates, and projections based on data up to 2004. Clin Res Cardiol 96:375-382

11. Dawkins KD, Grube E, Guagliumi G, Banning AP, Zmudka K, Colombo A, Thuesen L, Hauptman K, Marco J, Wijns W, Popma JJ, Koglin J, Russell ME, TAXUS VI Investigators (2005) Clinical efficacy of polymer-based paclitaxel-eluting stents in the treatment of complex, long coronary artery lesions from a multicenter, randomized trial: support for the use of drug-eluting stents in contemporary clinical practice. Circulation 112:3306-3313

12. Gleichmann U, Mannebach H, Lichtlen P (1985) Initial report on the structure and efficiency of the heart catheterization laboratory in the Federal Republic of Germany. Inquiry of the Commission for Clinical Cardiology of the German Society of Cardiology for the years 1979-1981. Z Kardiol 74:489-493

13. Gottwik MG, Senges J (2008) Kommentar zum 22 Bericht über die Leistungszahlen der Herzkatheterlabors in der Bundesrepublik Deutschland. Kardiologe 2:325-326

14. Gummert J, Funkat A, Beckmann A, Schiller W, Hekmat K, Ernst M, Haverich A (2008) Cardiac surgery in Germany during 2007: a report on behalf of the Germany Society for Thoracic and Cardiovascular Surgery. Thorac Cardiovasc Surg 56:328-336

15. Kastrati A, Mehilli J, Pache J, Kaiser C, Valgimigli M, Kelbaek H, Menichelli M, Sabaté M, Suttorp MJ, Baumgart D, Seyfarth M, Pfisterer ME, Schömig A (2007) Analysis of 14 trials comparing sirolimus-eluting stents with bare-metal stents. N Engl J Med 356:1030-1039

16. Koeth O, Bauer T, Wienbergen H, Gitt AK, Juenger C, Zeymer U, Hauptmann KE, Glunz HG, Sechtem U, Senges J, Zahn R, Maximal Individual Therapy in Acute Myocardial Infarction Plus (MITRA Plus) Study Group (2009) Angioplasty within $24 \mathrm{~h}$ after thrombolysis in patients with acute ST-elevation myocardial infarction: current use, predictors and outcome. Results of the MITRA plus registry. Clin Res Cardiol 98:107-113

17. Langer C, Wiemer M, Peterschröder A, Franzke K, Mellwig KP, van Buuren F, Koester-Eiserfunke W, Butz T, Diekmann J, 
Horstkotte D (2009) Stratification for noninvasive coronary angiography: patient preselection considering atypical angina pectoris, conventional cardiovascular risk assessment, and calcium scoring. Eur J Cardiovasc Prev Rehabil 16:201-209

18. Levenson B, Albrecht A, Göhring S, Haerer W, Herholz H, Reifart N, Sauer G, Troger B (2007) 5. Bericht des Bundesverbandes Niedergelassener Kardiologen zur Qualitätssicherung in der diagnostischen und therapeutischen Invasivkardiologie 2003-2005. Herz 32:73-84

19. Mandelzweig L, Battler A, Boyko V, Bueno H, Danchin N, Filippatos G, Gitt A, Hasdai D, Hasin Y, Marrugat J, Van de Werf F, Wallentin L, Behar S, Euro Heart Survey Investigators (2006) The second Euro Heart Survey on acute coronary syndromes: characteristics, treatment, and outcome of patients with ACS in Europe and the Mediterranean Basin in 2004. Eur Heart J 27:2285-2293

20. Mark B, Meinertz T, Fleck E, Gottwik MG, Becker HJ, Jünger C, Gitt AK, Senges J (2006) Stetige Zunahme der Prähospitalzeit beim akuten Herzinfarkt Eine Analyse der Entwicklung im bundesweiten Infarktregister (MITRAplus). Dtsch Arztebl 103:A1378-A1383

21. Morice MC, Serruys PW, Barragan P, Bode C, Van Es GA, Stoll HP, Snead D, Mauri L, Cutlip DE, Sousa E (2007) Long-term clinical outcomes with sirolimus-eluting coronary stents: fiveyear results of the RAVEL trial. J Am Coll Cardiol 50:1299-1304

22. Peterson ED, Dai D, DeLong ER, Brennan JM, Singh M, Rao SV, Shaw RE, Roe MT, Ho KK, Klein LW, Krone RJ, Weintraub WS, Brindis RG, Rumsfeld JS, Spertus JA, NCDR Registry Participants (2010) Contemporary mortality risk prediction for percutaneous coronary intervention: results from 588, 398 procedures in the National Cardiovascular Data Registry. J Am Coll Cardiol 55:1923-1932

23. Praz L, Cook S, Meier B (2008) Percutaneous coronary interventions in Europe in 2005. EuroIntervention 3:442-446

24. Ramsdale DR, Bray CL, Bennett DH, Ward C, Beton DC, Faragher EB (1986) Routine coronary angiography is unnecessary in all patients with valvular heart disease. $\mathrm{Z}$ Kardiol 75(Suppl 2):61-67

25. Schiele F, Hochadel M, Tubaro M, Meneveau N, Wojakowski W, Gierlotka M, Polonski L, Bassand JP, Fox KA, Gitt AK (2010) Reperfusion strategy in Europe: temporal trends in performance measures for reperfusion therapy in ST-elevation myocardial infarction. Eur Heart J [Epub ahead of print]
26. Serruys PW, Ong ATL, Piek JJ, Neumann FJ, van der Giessen WJ, Wiemer M, Zeiher A, Grube E, Haase J, Thuesen L, Hamm C, Otto-Terlouw PC (2005) A randomized comparison of a durable polymer Everolimus-eluting stent with a bare metal coronary stent: The SPIRIT FIRST trial. EuroIntervention $1: 58-65$

27. Silber S, Albertsson P, Aviles FF, Camici PG, Colombo A, Hamm C, Jørgensen E, Marco J, Nordrehaug JE, Ruzyllo W, Urban P, Stone GW, Wijns W (2005) Guidelines for percutaneous coronary interventions. The task force for percutaneous coronary interventions of the European Society of Cardiology. Eur Heart J 26:804-847

28. Silber S, Borggrefe M, Hoffmeister BöhmM, HM DietzR, Ertl G, Heusch G (2008) Medikamente freisetzende Koronarstents (DES) und Medikamente freisetzende Ballonkatheter (DEB): Aktualisierung des Positionspapiers der DGK. Clin Res Cardiol 97:548-563

29. Störk S, Ertl G, Nitschmann S (2010) Revaskularisation bei Patienten mit Typ-2 Diabetes und koronarer Herzkrankhiet. BARI 2D (Bypass Angioplasty Revascularization Investigation 2 Diabetes) Study Group. Internist 51:674-676

30. Tonino PA, De Bruyne B, Pijls NH, Siebert U, Ikeno F, van 't Veer M, Klauss V, Manoharan G, Engström T, Oldroyd KG, Ver Lee PN, MacCarthy PA, Fearon WF for the FAME Study Investigators (2009) Fractional flow reserve versus angiography for guiding percutaneous coronary intervention. New Engl J Med 360:213-224

31. Rosengren A, Steg PG, Tubaro M, Verheugt F, Weidinger F, Weis M, ESC Committee for Practice Guidelines (CPG), Vahanian A, Camm J, De Caterina R, Dean V, Dickstein K, Filippatos G, Funck-Brentano C, Hellemans I, Kristensen SD, McGregor K, Sechtem U, Silber S, Tendera M, Widimsky P, Zamorano JL, Silber S, Aguirre FV, Al-Attar N, Alegria E, Andreotti F, Benzer W, Breithardt O, Danchin N, Di Mario C, Dudek D, Gulba D, Halvorsen S, Kaufmann P, Kornowski R, Lip GY, Rutten F (2008) Management of acute myocardial infarction in patients presenting with persistent ST-segment elevation: The Task Force on the management of ST-segment elevation acute myocardial infarction of the European Society of Cardiology. Eur Heart J 29:2909-2945

32. http://www.bqs-outcome.de/2008/ergebnisse/leistungsbereiche/ PCI/buaw/index_html 